\title{
ECOFEMINIST VISIONS: RECENT DEVELOPMENTS AND THEIR CONTRIBUTION TO THE FUTURE OF FEMINISM
}

\author{
ESTHER REY TORRIJOS \\ Universidad Complutense de Madrid/GIECO/Instituto Franklin
}

Recibido: 22/03/2013

Aceptado: 09/10/2013

\begin{abstract}
Drawing from some of the leading ecofeminist critical works to date and considering the constant development of new perspectives and future strategies, the aim of my work is to explore some of the predominant vectors of the current ecofeminist theory and praxis. My plan is to review a significant part of the broad contours of the feminist debate since the beginning of the new millennium, proving that there have been substantial advances in both environmental and gender studies, most noticeably in North America, Australia and Europe. Focusing on the new material feminisms, interspecies and animal studies, ecojustice, queer studies, and ecofeminist bioethics, I have concentrated on the work of scholars and activists that are thinking, organizing and planning outside the traditional feminist frameworks and have generated cultural revaluations, have resisted gender injustice and have inspired environmental improvement.
\end{abstract}

Key-words: ecofeminism, new materialisms, animal studies, ecojustice, queer studies, bioethics.

\section{Resumen}

Partiendo de aportaciones críticas de algunas de las figuras claves del movimiento ecofeminista, el objetivo de mi trabajo es explorar el desarrollo actual y las estrategias futuras de las principales líneas de investigación y activismo dentro de esta corriente de feminismo ecológico. Tras una revisión breve de creciente imbricación de los estudios de género y la defensa medioambiental en los Estados Unidos, Australia y Europa, mi objetivo es revisar las tendencias actuales, surgidas a partir del nuevo milenio. La 
intención última es trazar los puntos de confluencia del feminismo actual con los nuevos materialismos, así como la implicación feminista en los movimientos de defensa de los derechos de los animales, de justicia ambiental, de integración homosexual y bioética, con la finalidad de destacar los más aptos para combatir la discriminación de género y la injustica social, y los mejor orientados a preservar el medioambiente.

Palabras clave: ecofeminismo, nuevos materialismos, defensa animal, justicia medioambiental, integración homosexual, bioética. 


\section{Introduction}

In the late 1970s ecofeminism appeared in North America as a new theoretical feminist perspective where sexism and environmental injustice were first connected and started to be examined together. Based on the premise that men and women do not exist apart from the environment, for the first time some feminist theorists who had concerned themselves with the progressive degradation of life in our planet contemplated and aimed to oppose gender and environmental domination all at once. In general terms, the specific ecofeminist argument was that, since the same social and economic structures that oppressed women were also causing wide-scale environmental damage, it seemed legitimate to think that women are better placed to speak on nature's behalf. ${ }^{1}$ As a result, the emergent synthesis of feminist and environmental movements soon started to link the growing natural decline and progressive resource depletion to the various forms of human oppression over other humans, as well as over nonhuman animals. ${ }^{2}$ Later, during the 1980s and 1990s, viewed either as a distinct discourse or as an amalgam of feminism and environmentalism, ecofeminism was gradually constructed and enriched by different feminist approaches, most of which challenged essentialism as a way of opposing the influence of social constructions in the relationships between men, women and the natural world. In other words, some feminist theorists started to pose a critique of the essentialist argument that women had a particular connection with nature by virtue of their biology, ${ }^{3}$ whereas other

1. For further reading on the issue of women's right to speak for themselves as well as for nature, see: DALY, Mary. Gyn/Ecology: the Metaethics of Radical Feminism, and SPRETNAK, Charlene. "Our Roots and Our Flowering", in Reweaving the World. The Emergence of Ecofeminism. Irene Diamond and Gloria Orenstein eds. San Francisco.

2. Within the animal rights movement, it is common to use the term "nonhuman animals" to imply that animals share a good number of characteristics with human beings, such as the capacity to feel pain and compassion, as well as certain intellectual skills or cognitive functions (i.e. memory). Hereafter, I shall be using the terms "animal" and "non-human animal" indistinctly, depending on the theoretical perspective and specific vocabulary of the theorist or activist that I am referencing.

3. The different degrees of tension between the essentialist and the cultural trends within ecofeminist theory can be traced in: SALLEH, Ariel K. "Deeper than Deep Ecology: The

Feminismo/s 22, diciembre 2013, pp. 17-46 
critical voices from environmentalism and the social sciences questioned the validity of a shared experience between humans and nonhuman others. ${ }^{4}$

Almost thirty years after the dawn of the ecofeminist project and well into the new millennium, North American leading feminist Greta Gaard presents in "New Directions for Ecofeminism: Toward a More Feminist Ecocriticism", and in "Ecofeminism Revisited: Rejecting Essentialism and Re-Placing Species in a Material Feminist Environmentalism", ${ }^{5}$ perceptive critiques of the current state of the ecofeminist phenomenon while openly admitting the gradual decline of the different forms of ecofeminist scholarship and activism. In both critical surveys, Gaard denounces the practical non-existence of analytical frameworks for gender, species and sexuality in the so called "third wave of ecocriticism", ${ }^{6}$ which comprises the latest tendencies in literary criticism on environmental literature and culture, and laments the omissions and misrepresentations of feminist literary criticism in some of the latest ecocritical works of the most prominent ecocritics to date. ${ }^{7}$ After acknowledging the even more alarming lack of interest among present feminists in appraising the unquestionable influence of the ecofeminist debate on the humanities and social sciences, Gaard asks "What has happened to ecofeminism?", 8 and immediately proceeds to answer the question herself by offering an extensive overview of the origins and evolution of the ecofeminist movement, from the 1980 s to the first decade of the new millennium, offering an enlightening perspective on the fusions and discordances between the feminist pursuits and a variety of ecological causes with which ecofeminists have shared a common

Eco-Feminist Connection"; Merchant, Carolyn. The Death of Nature: Women, Ecology and the Scientific Revolution, and Earthcare, Women and the Environment; PLUMWOOD, Val. Feminism and the Mastery of Nature; and WARREN, Karen J. ed. Ecological Feminist Philosophies.

4. For a pioneering study of the human association with the nonhuman, see Jim JoHnSON's "Mixing Humans and Nonhumans Together: The Sociology of a Door-Closer".

5. GAARD, Greta. "New Directions for Ecofeminism: Toward a More Feminist Ecocriticism". Although it was published by ISLE, I shall be referring to the online version henceforth, at http://gretagaard.efoliomn.com/Uploads/isle.isq108.full.pdf. Accessed Jan. 2013; see also the online version of "Ecofeminism Revisited: Rejecting Essentialism and Re-Placing Species in a Material Feminist Environmentalism, at http://www. readbag.com/gretagaard-efoliomn-uploads-ecofeminismrevisited2011. Both of them last accessed in Jan 2013.

6. Mentioned as such for the first time in Adamson, Joni and Scott Slovic, eds. "The Shoulders We Stand On: An Introduction to Ethnicity and Ecocriticism".

7. For more specific reference, see GAARD, Greta. "New Directions". Op. cit., p. 2.

8. GAARD, Greta. "Ecofeminism Revisited", Op. cit., p. 27. 
experience. ${ }^{9}$ Deliberately limiting the scope of her study to North American ecofeminism, though generally alluding to the contributions of Canadian, Australian, Indian and Northwestern European theorists and activists, Gaard explains that over the last decade the philosophical synthesis of movements formerly known as "ecofeminism" has undergone a constant process of renaming, which responds to a need for redefinition and a compulsive tendency to reappraise the essential aspects of its theory and praxis. Her scrutiny clearly exposes the more active forms of feminist and environmentalist resistance to ecofeminist analyses, all of which have considered essentialism and ethnocentrism as the first causes of controversy for being "irrelevant distraction(s) from feminism's more critical work addressing social injustices". ${ }^{10}$ Similarly, ecofeminism's excessive tendency to embrace an almost religious spirituality and its constant drift into apolitical inactivity and individual self-contemplation have combined with a lack of appreciation for the materiality of things to prevent ecofeminists from engaging in practical earthly struggles at local, community and global levels, concerning both ecological and social issues. Admittedly, inactivity has proved to be one of the most detrimental causes of the current ecofeminist decline which, in combination with the disparity of approaches and the multiplicity of connections with antiracist, postcolonial, antimilitary, social justice and animal rights activism, have all weighed down the ecofeminist project and made it seem almost irrelevant both for the feminist and for the environmental schemes. As Gaard observes:

Ecofeminism in the 1980s was indeed a broad umbrella for a variety of diversely inflected approaches, some of which were rooted in essentialist (cultural) feminisms, just as others grew out of liberal, social, Marxist, anarchist, and socialist feminisms, and in the 1990s, ecofeminist theories continued to refine and ground their analyses, developing economic, material, international, and intersectional perspectives. ${ }^{11}$

Even though some of the charges against ecofeminism seem "sweeping generalizations, often made without specific and supporting documentation", ${ }^{12}$ the accusations have left indelible marks on the social and academic relevance of the movement and on its future prominence, to such an extent that:

9. For an overview of the origins and evolution of the ecofeminist movement written for Spanish speakers, see REY, Esther. "¿Por qué ellas? ¿por qué ahora? Orígenes y Evolución de la Síntesis Ecofeminista”, Ecocríticas. Literatura y Medioambiente. Eds. Carmen FuYs et al.

10. GAARD, Greta. "Ecofeminism Revisited". Op. cit., p. 41.

11. Ibid., p. 32.

12. Ibidem.

Feminismo/s 22, diciembre 2013, pp. 17-46 
By 2010, it was nearly impossible to find a single essay, much less a section, devoted to issues of feminism and ecology (and certainly not ecofeminism), species, or nature in most introductory anthologies used in women's studies, gender studies, or queer studies. ${ }^{13}$

To further illustrate the present state of affairs in the ecofeminist decline, Gaard describes how a decade ago the editors of Signs: Journal of Women in Culture and Society, a leading academic feminist journal, rejected a review essay on ecofeminism that had been commissioned by its managing director a year earlier, on the grounds that:

Ecofeminism seems to be concerned with everything in the world $[\ldots]$ and (as a result) feminism itself seems almost to get erased in the process [...] When ecofeminism contains all peoples and all injustices, the fine tuning and differentiation lose out. ${ }^{14}$

The accusation seemed rightly grounded and, as the academic neglect prospered, similar reviews and articles fared little better and were equally rejected by skeptical journal boards, the outcome being that mistrust and apprehension for the ecofeminist ideal became the norm, not only from feminist advocates but also from deep ecologists, social ecologists, animal liberationists and other environmental movements. ${ }^{15}$ It seems only logical that, feeling incapable of rejecting the adverse implications of those charges for the future of the movement, and in order to gain a wider audience and intellectual acceptance in academic circles, most scholars and activists working on environmental and gender issues abandoned institutions and terms that no longer functioned as conduits for critical ideas and continued their work under different academies and labels. Thus, during the first decade of the new century, a good number of new terms were coined to define the new realities of ecofeminist theory - ecological feminism, feminist environmentalism, social ecofeminism, critical feminist eco-socialism and gender and the environment studies are just one part of a longer list - to sidestep ostracism and to counteract the general lack of academic appreciation. ${ }^{16}$ Simultaneously, as an outcome of

13. Ibid., p. 31.

14. Ibid., p. 32-33.

15. Ibid., p. 27. Further evidence of subtle or open censorship appears in Noël Sturgeon's personal anecdotes:"I was once advised by a prominent feminist theorist [...] to remove the word "ecofeminism" from the title of one of my papers [...] I have been advised by a feminist mentor to leave my editorship of The Ecofeminist Newsletter off my vita [...] I have been challenged during a conference presentation to call my position feminist rather than ecofeminist [...]" In STURGEON, Noël. Ecofeminist Natures. Race, Gender, Feminist Theory and Political Action, p. 6.

16. Ibid., p. 41. 
ecocriticism's expansion beyond its multiple and continuous developments, ecofeminist literary criticism stemmed from the North American, Australian and Northwest European ecocritical branches during the late 1990s. Thereafter, after reaching ecocritics in Japan, China and Taiwan, ecofeminist literary criticism finally became a form of activism committed to literary criticism as a strategy for ecodefense. ${ }^{17}$

Coinciding in time and mission with Gaard's perceptive critical work, in the foreword to Ecofeminism and Rethoric: Critical Perspectives on Sex, Technology and Discourse, Glynnis Carr notes that, although today few people call themselves ecofeminists, many theorists are working toward the kind of future envisioned by ecofeminist epistemology. Although the sustained lack of critical appreciation seems inconsequential and rather unfair, Carr claims that the public acceptance of the ecofeminist message is nonetheless relevant for the future of the movement because it means that its fundamental ideas are still visible in academic circles, probably the most important sites for the production of knowledge, ideology and culture. It is no secret that scholars in fields outside of feminism - such as posthumanism, postcolonialism and animal studies - are moving forward in their research using ideas initially developed in ecofeminist discourse, ${ }^{18}$ and are circulating the message in the academia, making it visible in an increasing number of university departments, as part of both graduate and postgraduate environmental and women's studies programs. ${ }^{19}$

Drawing from Gaard's ecocritical views and considering the latest developments in the feminist perspectives on social justice, feminist psychology and interspecies studies, the aim of this essay is to explore some of the new trends in current ecofeminist theory and praxis ${ }^{20}$. My plan is to review one part of the broad contours of the ecofeminist debate from the start of the new millennium, proving that there have been substantial advances in the US

17. See GAARD, Greta. "Strategies for a Cross-Cultural Ecofeminist Literary Criticism", Ecozon@, vol. 1, p. 47.

18. CARR, Glynnis. Foreword to Ecofeminism and Rethoric: Critical Perspectives on Sex, Technology and Discourse. Douglas A. VAKOCH ed., p. 42.

19. An increasing number of North American university colleges are currently offering courses and seminars on ecofeminism and women's studies, many of them closely related to environmental studies. For reference and programs, http://www.gradschools. com/programs/humanities-cultures.

20. As this volume went to the press, a very recent publication, which I would have otherwise included in my bibliographical reference, came to my hands. Edited by G. Gaard, S. C. Estok and S. Oppermann, International Perspectives in Feminism Ecocriticism offers a variety of views, which add much to the vitality of the future of the ecofeminist project. I thank Serpil Oppermann for forwarding the volume to me.

Feminismo/s 22, diciembre 2013, pp. 17-46 
and Northwest Europe in both environmental and gender studies. Without pretending to present a comprehensive analysis of the diversity of routes, a task which would require much more time and space than the brevity of this essay allows, my intention is to focus my exploration on the most prominent tendencies in new material feminisms ${ }^{21}$, as well as on interspecies and animal studies $^{22}$, ecojustice ${ }^{23}$, queer studies ${ }^{24}$, and some of the groundbreaking studies in ecofeminist bioethics, ${ }^{25}$ in the understanding that each advancement is in itself a revision, an interrogation and a step forward for every development that has preceded and inspired it. However, even though each breakthrough owes much to the scope and depth of the ongoing theoretical debate, it is also necessary to bear in mind that most of the theoretical shifts operate within existing structures, something which undoubtedly limits their capacity to create social change. For that reason, my work intentionally concentrates on the contributions of Northamerican and Northwest European feminist scholars and ecocritics who have been thinking, organizing and planning to provoke political and cultural change. The scope and depth of their approaches, either from feminism or from ecocriticism, makes them likely to generate the drastic social shifts and cultural revaluations that seem essential to combat gender injustice and contribute to environmental improvement.

\section{New material feminisms}

Regarding academic attention, material feminism can, in many ways, be considered a critical methodology approaching its peak. Assuming that in the past postmodernist scholars had already analyzed a range of social discourses and cultural artifacts that served to reflect the physicality of the body and the materiality of the natural world, it seems that, when discussing the role of

21. See Alaimo, Stacy and Susan Hekman eds. Material Feminisms; DolPhijn, Rick and Iris VAN DER TUIN. New Materialism: Interviews and Cartographies.

22. See ADAmS, Carol J. The Sexual Politics of Meat, and "Why Feminist-Vegan Now?". See also jones, pattrice. Aftershock: Confronting Trauma in a Violent World.. Finally, for a thorough analysis of anthropocentrism and animal communication, see ARMBRUSTER, Karla. "What Do We Want from Talking Animals", in Speaking for Animals. Animal Autobiographical Writing, Margo Demello ed.

23. For an excellent example of an ecofeminist perspective on reproductive justice, see GAARD, Greta. "Reproductive Technology or Reproductive Justice? An Ecofeminist Environmental Justice Perspective on the Rhetoric of Choice".

24. See Sarah AHMED's Queer Phenomenology. Orientations, Objects, Others. Also, MorTimER-SANDILANDS, Catriona and Bruce ERICKSON eds. Queer Ecologies: Sex, Nature, Politics, Desire.

25. See Grace KaO'S "Consistency in Ecofeminist Ethics" and Marti KhEEL's, Marti. Nature Ethics. An Ecofeminist Perspective. 
language in the constitution of social reality, the specific feminist interest had exclusively concentrated on the discursive practices that had traditionally molded the social and material realities of women, of racial and ethnic minorities, and of the nonhuman world. However, after admitting that the analyses of social discourse have been extremely productive for the feminist project, the advocates of the new material feminisms now consider that the retreat from materiality has also had its drawbacks, the most obvious being that, by focusing exclusively on representation, ideology and discourse - in search of the linguistic idealism conveyed in Derrida's "there is nothing outside the text"26 - a whole body of lived experiences, corporeal activities and biological practices have been excluded from academic analyses. ${ }^{27}$

Considering the first stages of the new materialist approach, it was Rosi Braidotti who first coined the term "neo-materialism", provided a genealogy of it and started a radical re-reading of the concept of materialism as had been formerly developed by Canguilhem, Foucault and Deleuze. ${ }^{28}$ Neo-materialism emerged as a method, a conceptual frame and a political stand which refused the linguistic paradigm and stressed the complexity of the materiality of bodies immersed in power structures. In Braidotti's groundbreaking view, the postmodern materialist representational method of thinking and its thoroughly linguistic turn soon became utterly outdated and, therefore, in need of redefinition in the light of the recent scientific insights, notably the rise of psychoanalysis and the wide scope of socioeconomic changes caused by capitalism..$^{29}$

As Dolphijn and Van der Tuin have pointed out in New Materialism: Interviews and Cartographies, Braidotti's modern feminist materialism has two influential theoretical traits, the first being that it goes further than the mainstream philosophy in rejecting partitions of minds from bodies or nature from culture, the second that it does not stop at critical deconstruction, but goes on to provide alternatives. For example, it introduces a break from the humanist inclination to universalism and criticizes it for being disembodied and disembedded, that is, abstract. Relying on Deleuze's theories of alterity and otherness, today feminist materialists place emphasis on processes, dynamic interactions and fluid boundaries when discussing the materiality of

26. DERRIDA, Jacques. Of Grammatology, p. 163.

27. Besides Alaimo and Hekman's Material Feminisms, see also Coole, Diane and Samantha Frost eds. New Materialism. Ontology, Agency and Politics.

28. See an interview with Rosi Braidotti, in Rick DOLPHIJN and Iris VAN DER TUIN's New Materialism: Interviews and Cartographies. 19-37.

29. Ibid., pp. 159-160.

Feminismo/s 22, diciembre 2013, pp. 17-46 
women's bodies and, more generally, of the natural world. ${ }^{30}$ In other words, while distancing themselves from the postmodernist sheer concentration on social discourse, emergent groups of feminist theorists have argued for the need to consider the materiality of the human body and of the natural world as active forces that have been denied the relevance they deserve. Working under different labels - material feminism ${ }^{31}$ or new materialism ${ }^{32}$-, they have challenged, criticized and drawn inspiration from the productive language of discourse and text studies so actively important for postmodernism, and have tried to recuperate the prediscursive aspects of bodies and matter, the "transversality" - echoing Guattari ${ }^{33}$ - of the corporeal relations between bodies and environments, and the relevance of nonhuman actors or "posthuman" beings. $^{34}$

In the introduction to Material Feminisms, Alaimo and Hekman insist that the materiality of both the human and the more-than-human world must be taken seriously, and call for an imminent reconceptualization of nature and an appreciation of its agency: "Nature is agentic - it acts, and those actions have consequences for the human and nonhuman world". ${ }^{35}$ Once that is understood, it follows that humans need to find ways of recognizing "the agency, significance and ongoing transformative power of the world", bringing ourselves to establishing a dialectical egalitarian relationship with the genuinely material aspects of our existence. Drawing from previous feminist conceptions of the human, nonhuman, technological and natural agents that interact and jointly contribute to the construction of the role of women and others in

30. Ibid., pp. 21-23.

31. Mentioned as such in the title of AlAIMO and HEKMAN's edited volume (2008).

32. See, for example, Squier, Susan and Melissa M. LitTlefield. "Feminist Theory and/ of Science"; BARRETT, Estelle and Barbara BOLT eds. Carnal Knowledge. Towards a New Materialism Through the Arts. Finally, the same label appears in the title of the aforementioned DOLPHIJN and VAN DER TUIN's New Materialism (2012).

33. In 1989, Félix GUATTARI developed the idea of thinking transversally when conceiving of nature and culture in Las Tres Ecologías, p. 33.

34. For further reading on the concept of the "posthuman", see Nick Bostrom's "Why I Want to Be a Posthuman When I Grow Up", at http://www.nickbostrom.com/posthuman.pdf.

35. Karen BARAD proposes the idea of "agential realism", which allows her to establish that the "so-called subject, the so-called object and the so-called instrument of research are always already entangled". If matter and meaning are already entangled, there is just one step to the notion that matter "feels, converses, suffers, desires and remembers", because "feeling, desiring and experiencing are not singular characteristics or capacities of human consciousness" (Introduction to DOLPHIJ and VAN DER TUIN'S New Materialism, p. 15). For an interview with Karen BARAD, see DOLPHIJN and VAN DER Tuin, pp. 48-70. 
the modern world ${ }^{36}$ the contributors to Material Feminisms endeavor to fill the material vacuum in contemporary feminist theory and praxis. Their work articulates what in feminist theory has come to be known as the "material turn", ${ }^{37}$ that is, a reevaluation of the traditional conception of nature as a mere resource for technological progress and social construction, and an appreciation of its agency, significance and transformative power.

Amongst the analyses collected in the above cited volume, Elizabeth Grosz's reappraisal of Darwin's evolutionary theory and her reliance on biology to develop new feminist critiques of science in "Darwin and Feminism. Preliminary Investigations for a Possible Alliance" seem congruous with the current feminist need to undertake complex and subtle analyses of what biology is and consider how it has facilitated and made possible the existence of certain cultural patterns. Undoubtedly, a reappraisal of the role of biology seems only coherent if feminism aims to effectively challenge the established positions toward women and science in our modern world. ${ }^{38}$ Equally relevant seem Nancy Tuana's meditations on the devastation caused by the hurricane Katrina in the city of New Orleans. In "Viscous Porosity: Witnessing Katrina" Tuana articulates a material feminist revision of the agency of nature as a basic standpoint, an agency diffusely enacted in a variety of ways within a complex network of social modes and relations where reality is conceived as multiple, porous, dynamic and always interactive. ${ }^{39}$ Seeing through the eyes of a category four hurricane makes Tuana understand the porosity of the categories "human-made", "natural", "social" and "biological", and inspires her to develop her theory of "viscous porosity" as a strategy to reflect the sheer transversality of nature and culture, language and reality. Even more inspiring seems Susan Bordo's "Casey's Hair", which provides a practical example of how the biological and the social aspects of human existence interact in multiple ways. Bordo uses the materiality of her biracial daughter's hair as an example of how the perceptions of physical differences - in this case Afro-Americans' hair and

36. See Donna Haraway, "The Promises of Monsters: A Regenerative Politics of Inappropriate/d Others at http://www.zbi.ee/ kalevi/monsters.html. Also Karen BARAD, "Getting Real: Technoscientific Practices and the Materialization of Reality", and Catriona MORTIMER-SANDILANDS, "Lavender Green? Some Thoughts on Queer(y)ing Environmental Politics".

37. In Alaimo and Hekman. Material Feminisms. Op. cit., p. 6. See also Serenella IoviNO's rendering of the existence of a material turn in environmental philosophy and ecological humanities, in "Theorizing Material Ecocriticism: A Diptych", http://www. academia.edu/Documents/in/Material_Ecocriticism.

38. Ibid., pp. 23-51.

39. Ibid., pp. 188-213.

Feminismo/s 22, diciembre 2013, pp. 17-46 
hairstyling - can facilitate our understanding of how the physicality of the body is inextricably linked to the social, the cultural and the racial aspects of human existence. ${ }^{40}$

On the whole, the most significant aspect of the entire issue of materiality seems to be the reappraisal of the concept of matter and, more specifically of nature, not as a blank, silent resource to be exploited by culture, but as an active, signifying agent in its own terms. From now onwards, the ability to feel and desire cannot be restricted to humans, and neither matter, nature nor nonhuman animals can ever again be considered the mirror images of culture, but agents in their own rights. As feminist materialists claim, the act of attending to the materiality of things should be the first tactical step to erase the boundaries between human and nature, body and environment, mind and matter, and the new materialisms seem intent on doing this in much more straightforward ways than the often overlapping fields of environmental philosophy, environmental feminism and green studies have so far dared to envision.

\section{Interspecies and animal rights feminisms}

From the late 1980s, feminist writers attentive to environmental issues have been consistently illustrating the extension of feminist and environmental concerns into animal rights, in the genuine belief that women, nonhuman animals and the environment have shared a tendency to be consigned to a dualistic otherness, a fact which must be understood as one of the multiple aspects of a continuous interconnected system of shared oppressions. ${ }^{41} \mathrm{~A}$ pioneer thinker in this field, Carol J. Adams explained in The Sexual Politics of Meat that meat eating has traditionally been associated with power and virility, ${ }^{42}$ and has been used to boost feelings of fraternity among individual male consumers who, from generation to generation, have sustained the idea that men should eat meat and women should prepare and serve it. ${ }^{43}$ It goes without saying that Adams associates meat consumption with sexism and

40. Ibid., pp. 400-424.

41. For insightful analyses of the perceptions and assumptions that sustain most human relationships to nonhuman animals, see Donna HARAWAY's The Companion Species Manifesto: Dogs, People, and Significant Otherness, and When Species Meet; also Joni SEAGER's "Pepperoni or Broccoli? On the Cutting Edge of Feminist Environmentalism", and Val PLUMWOOD's claim for a dialogical interspecies ethics in Environmental Culture: The Ecological Crisis of Reason.

42. Op. cit., p. 48.

43. Ibid., p. 42. 
classism, and suggests that food decisions have traditionally been, and will always be, coded ways of resistance. Considering the connections between food and feminism, Adams suggests that a good number of feminists have become vegetarians because this makes sense as one part of their anti-subjugation attitude, a logical strategy of resistance within the logic of patriarchal culture. For Adams, vegetarianism is pure feminist activism, and so The Sexual Politics of Meat establishes that ideas about meat are, in fact, beliefs and convictions about dominance and power, primarily over animals, but more extensively over women and other less favored humans.

As was to be expected, since the first stages of the process, the emergent feminist empathy for animal suffering was soon rejected both by the antifeminist and by the meat eating worlds. Simultaneously, vegetarianism and animal rights activism were feminized and cruelly mocked by male environmentalists and animal rights advocates who, as Adams ironically explains in "Why Feminist-Vegan Now?", considered it a passing craze among "emotional little old ladies in tennis shoes". ${ }^{44}$ Accordingly, the animal rights movement was catapulted into respectability only when Tom Regan and Peter Singer - appropriately, two white male philosophers - started to theorize about the motives for animal liberation as legitimated either by recourse to animal rights ${ }^{45}$ or attention to animal suffering. ${ }^{46}$ Curiously enough, their achievements were better valued for the fundamental reason that men's voices were felt to be more entitled to be heard than women's voices, even when concerning animals or women's rights. ${ }^{47}$ However, even if ecofeminists distanced themselves from certain aspects of these male philosophers' deontological theories on animal rights, they shared their underlying desire to submit their ordinary interactions with animals to moral scrutiny, objecting to the culturally accepted treatment of the species consumed as meat, and recognizing how our daily practices annihilate the subjectivity of what Adams calls the "absent referents". ${ }^{48}$ The important fact remains that today most feminists and animal rights defenders understand that all living beings are interconnected, and that there will be no real liberation for women if the world is not liberated from speciesism as well. Following this line of thought, some feminist scholars have gone so far as to undo the line of demarcation between humans

44. Op. cit., p. 314.

45. See Regan, Tom. The Case for Animal Rights.

46. See Singer, Peter. Animal Liberation.

47. AdAms, Carol. "Why Feminist-Vegan Now?". Op. cit., pp. 313-314.

48. In Adams, Carol. The Sexual Politics. Op. cit., p. 51.

Feminismo/s 22, diciembre 2013, pp. 17-46 
and animals by challenging the animal/human dualism,${ }^{49}$ and by emphasizing how clearly related sexual and animal justice have been and will continue to be in the future. In this sense, Adams still finds reasons to denounce the same process of objectification, fragmentation, and consumption of women's and animals' bodies, a historical process whose implications are more than ever present as part of a long deeply embedded continuum that enables and legitimizes both types of oppression, as it renders them "being-less through technology, language, and cultural representation". ${ }^{50}$ In her critique, Adams finds a variety of examples of overlapping cultural images of sexual violence against women and the fragmentation and dismemberment of animals in Western culture, showing that there has traditionally been one unequivocal movement: animals are consistently feminized and women are persistently animalized and, in both cases, the final outcome is objectification, a process legitimized by the use of a dominant type of language in which the meaning of the violent appropriation is negated or transformed into metaphors, often applied to both animals and women. ${ }^{51}$

More recently, the theoretical impulse of the movement has taken a step forward with the publication of a special issue of Hypatia ${ }^{52}$ dedicated to animal studies, containing contributions of leading animal rights advocates who explore a range of complex issues, such as the various ways to balance conflict between both forms of oppression and, from a bioethical perspective, the question of animal rights as related to meat eating, vegetarianism and veganism. The wide variety of approaches, as posited in the call for papers, illustrates the relevance of the ongoing debate occurring within feminist animal studies, mainly motivated by the effort to explore the mutually reinforcing interconnections among diverse forms of oppression. Interconnections that, as Gaard claims in her contribution to the 2012 Hypatia symposium centered on "Speaking of Animal Bodies", are essential because, from an ecofeminist perspective, the reproductive and sexual enslavement of female nonhuman and human bodies has always occurred and has always raised ethical concerns. Moreover, the analysis of such connections should contribute to extend

49. See BIRKE, Lynda and Luciana PARISI. "Animals, Becoming", Animal Others: On Ethics, Ontology and Animal Life, Peter STEEVES ed.

50. ADAMS, Carol. "Why Feminist-Vegan Now?". Op. cit., p. 304.

51. Ibidem. See also how Adams criticizes PETA (People for the Ethical Treatment of Animals) for using models and celebrities wearing sexy outfits for their campaigns on animal rights, claiming that "at PETA only women are treated like meat". For PETA's current campaigns, see http://www.peta.org/. Accessed Jan. 2013.

52. Hypatia, 27.3 (August 2012). http://onlinelibrary.wiley.com/doi/10.1111/hypa.2012.27. issue-3/issuetoc. Accessed Jan. 2013.

Feminismo/s 22, diciembre 2013, pp. 17-46 
the theory from the realm of the purely intellectual to that of the political, exposing the broader implications and deeper roots of the treatment we give to animals, making activism more relevant and illustrating our own role in oppressive structures as consumers of suffering, as contributors to climate change and as sponsors of global food scarcity. ${ }^{53}$

Perhaps most radically, in the January 2005 issue of Satya, pattrice jones pleaded for meaningful, purposeful coalitions between animal liberationists and feminists, since speciesism and sexism are not separate but overlapping problems. In her words, "women and animals, along with land and children, have historically been seen as the property of male heads of households, who then compete with other men for more power and property".${ }^{54}$ In the process, women have been cut off from their bodies in different ways, as historically different peoples have embraced philosophies and religious faiths that have asked them to consider female bodies as profane objects to be transcended. As a result, women have come to view their bodies as something other than themselves. From that first division derives the subdivision of the female body into a collection of body parts and, in jones' words, "experiencing ourselves in such a fragmented manner, it is no wonder that men reduce women to their body parts in pornography or that the everyday butchery of animals into their body parts seems so natural". ${ }^{55}$ Additionally, since early childhood humans have been traumatized by the lies they've been told about their relationship to animals, conditioned to be disconnected from nature, and discouraged to feel any empathy for any being that is not human. As a necessary response to such lies and traumas, in Aftershock: Confronting Trauma in a Violent World: A Guide for Activists and Their Allies ${ }^{56}$, jones offers a selection of self-care strategies for those social change activists who are in need of support while dealing with the trauma of having been deceived into meat eating for years. ${ }^{57}$

From an altogether different perspective, in "Mortal Love: Care and Practices in Animal Experimentation", feminist theorist Tora Holmberg renders a diametrically opposed view when discussing the relationship of care that may occur within certain laboratories dedicated to animal experimentation.

53. For the complete transcript of GAARD's contribution, see http://thephilosopherseye. com/2012/07/09/hypatia-symposium-greta-gaard/. Accessed Jan. 2013.

54. See Satya. Jan. 2005, p. 1. http://www.satyamag.com/jan05/jones.html. Accessed Jan. 2013.

55. Ibid., p. 1.

56. For specific reference, see previous footnote.

57. For more recent contributions, see jones' afterword to Sistah Vegan (New York: Lantern Books, 2010), which shows further analyses of inter species psychology and ecojustice activism.

Feminismo/s 22, diciembre 2013, pp. 17-46 
Building on previous theoretical work on animal studies and feminist ethics, Holmberg demonstrates that empathy and affection for individual animals are possible, and can be important components of the experimentation ethos, not as mere justification of the harm and killing performed, but as intrinsic dimensions of the human-animal relations. ${ }^{58}$

Focusing on a different side of the prism, sociologist Grace Kao considers that placing much emphasis on animals' sentience causes discomfort among feminists, since the animal rights debate may negatively influence certain aspects concerning women's reproductive rights of choice and, more specifically, may affect the abortion debate. As Kao claims in "Consistency in Ecofeminist Ethics", animal pain is arguably comparable to fetal pain in that we can only reason about either by analogy. Hence the feminist reluctance to embrace the animal rights cause, and the internal division among feminists on whether they ought to champion the interests of animals or concentrate on working exclusively on the different aspects of women's liberation. While some ecologically-minded feminists have advanced contextual moral vegetarianism as a logical outcome of feminism, other feminists are non-committal or even hostile to that view for a variety of reasons, the most important being the well-grounded suspicion that animal advocacy might affect the abortion debate in a manner unfavorable to women's reproductive right of choice. So Kao writes:

Even if vegetarianism were the only morally defensible diet for most global Northerners, it remains unclear whether this view could be defended without incurring "collateral damage" from the perspective of more conventional feminist commitments. By unintended, undesirable, though seemingly unavoidable consequences, I have in mind certain concessions concerning abortion. ${ }^{59}$

In spite of the abundance of differing approaches, the truth is that for some decades ecofeminists have seen their liberation and self-respect as fundamentally connected to the well-being of nonhuman others. This seems a logical connection, since the characteristic topics of reproduction and consumption extensively explored within animal studies have traditionally been considered key issues within feminist epistemology. Feminists are well aware that female bodies do most of the labor in reproduction, and in most human cultures both female human and nonhuman bodies have been historically used either to provide food, or to cook and serve it.

58. Holmberg, Tora. "Mortal Love: Care and Practices in Animal Experimentation", at http://fty.sagepub.com/content/12/2.toc. Accessed Nov. 2012.

59. KAO, Grace. Op. Cit., p. 1.

Feminismo/s 22, diciembre 2013, pp. 17-46 
In the last decade, the most controversial question was whether the ecofeminist drive toward moral vegetarianism must come at the expense of more conventional feminist commitments, such as women's self reproductive right of choice, since the arguments used in one context can be readily applied to the other as well. In search of a necessary compromise, relying on bioethical notions of contextual versus universal moral vegetarianism, on theories of animal moral standing, and on the recurrence to an "ethics of care" toward animals, Kao safely confirms that on no account needs the animal liberation movement affect women's reproductive freedom and body integrity, and concludes that both feminism and vegetarianism stand to gain from the integration of both liberating approaches. ${ }^{60}$

\section{Ecofeminism and environmental justice}

The environmental justice movement has consistently grown in scope since it primarily emerged to denounce a variety of experiences of environmental inequalities based on race, ethnicity and poverty. While to this day ecofeminism has never claimed to be part of the same movement, both schools of thought clearly share a number of characteristics as, from the micro to the macro level, women from the most disfavored races, ethnic groups or social levels have traditionally been more likely than men to be classified as in poverty'. Accordingly, in the development of the ecofeminist project, theorists and activists soon realized that they needed to integrate issues of race and class with gender if they wanted to go further in their analyses of the social reasons for women's oppression. Following the lead, the environmental justice literature, previously dominated by poverty and race issues, also began to address gender ${ }^{61}$ as there was accumulating evidence that gender has always been disproportionately associated with social disadvantage in a number of ways. Nevertheless, despite the increasing confluences and similarity of creeds, a number of conceptual discordances between both movements have also appeared on the horizon for, as Gaard reveals:

Ecofeminists have tended to be some combination of identities that may include first-world, white, middle-class, vegan or vegetarian, lesbian or bisexual identities. Spokespeople for environmental justice women activists have tended to be women of color, working class, heterosexual, and/or omnivores.

60. Ibid., p. 12.

61. See Buckingham, Susan. "Ecofeminism in the $21^{\text {st }}$ Century". Online version: http:// www.studymode.com/essays/Ecofeminism-In-The-21St-Century-414055.html.

Feminismo/s 22, diciembre 2013, pp. 17-46 
Thus, multi-directional tensions about homophobia, speciesism, classism, and racism have precluded many real, on-the-ground alliances. ${ }^{62}$

It seems that while ecofeminism initially concentrated on gender, species and sexuality, environmental justice movements largely focused on race and class. Even so, in spite of their own idiosyncrasies, both theoretical developments have always been careful to adopt an inclusive perspective capable of resisting the rise of one privileged category over the others. So much so that nowadays it seems safe to say that, beyond those sources of conflict and primary focal points, ecofeminism and environmental justice must be considered complementary theories and movements since, as Gaard pointedly notes, feminists and ecofeminists are the earliest proponents and primary midwives of environmental justice ecocriticism. ${ }^{63}$

More concretely, from the first antimilitarist protests organized by feminist groups during the 1980s - namely, the Women's Pentagon Action, in the US, and the peace camp at the US Airforce Base of Greenham Common, in England - ecofeminism has traditionally considered militarism as central to the oppression of women and to the destruction of the nonhuman world. Likewise, the ecofeminists of the 1990s blamed military organizations for causing more ecological trouble than any other social institution, denouncing the fact that they have traditionally been assigned massive budgets that otherwise could have been used for socially useful programs, and have generated a culture of violence which is in itself profoundly racist, sexist and environmentally disrespectful. Finding inspiration in those early protests, an increasing number of grassroots networks in the US and Europe have manifested their deep concern for social and environmental issues, using political confrontation and public education as modes of challenge in the public arena. Using more practical strategies than other feminist groups, environmental justice feminists have always located the environment not is some distant or abstract place, but within homes, schools, workplaces and neighborhoods, a pragmatic approach which has promoted the creation of countless women's groups willing to campaign for gender equality and environmental justice. Amongst the most socially visible, WEDO (Women's Environment and Development Organization) was founded in the 1990s to advocate for gender equality in global policy. Based in the US, with Wangari Maathai as former board member, WEDO has consistently taken an active part in UN conferences and ensured women's equality, motivating the inclusion of fundamental

62. GAARD, Greta. "New Directions". Op. cit., p. 6.

63. Ibid., p. 5. 
women's rights in the final documents of Agenda 21 and the Rio Declaration on Environment and Development (1992). ${ }^{64}$ In the UK, WEN (Women's Environmental Network) has been established for over two decades, with more than 38 local groups and over 2,500 participants campaigning for sensible consumption, waste minimization and conscious consumerism, while taking an interest in local food growing, seed saving, and the development of energy-efficient programs. ${ }^{65}$ Similarly, WHEN (Women's Health and Environmental Network) started in the late 1990s to protest environmental chemical exposure. Former members of breast cancer associations, its founders have campaigned in different states of the US to protect women's health and ensure a safer environment. ${ }^{66}$ Amongst the earliest and most influential publications, Canadian WEI (Women's and Environments International Magazine) first issue appeared in the 1970s, and is currently considered one of the longest surviving feminist magazines in Canada. Over the years, its contributors have analyzed women's multiple associations with the environment, from feminist and antiracist perspectives, in issues centered on women and toxins (2008), labor and the environment (2011) and food security (2012). The number and variety of networks and publications makes it impossible to comment on them all, even if it means excluding the equally important activist practices related to long-term women's land projects, newsletters and periodicals, study groups and retreat centers, whose main objectives are to share knowledge about environmental issues and policies relevant to environmental and gender injustice.

Simultaneously, official institutions have progressively engaged in fighting gender inequality. In 2000 the UN Division for the Advancement of Women mandated the preparation of an in-depth study on all forms of violence against women. ${ }^{67}$ One decade later, Lakshmi Puri, Deputy Director and Assistant Secretary-General of UN Women pointed out at the National Committee's Meeting in Sydney Sep 2011 that women suffer even more due to natural disasters, climate change, environmental stress, food, fuel, health and economic crises as they bear the burden of care-giving. Although their contribution to economic growth is substantial in both developed and developing countries, the majority of women are in vulnerable jobs and gender wage gaps are still large. In addition, women make up two-thirds of the world's illiterate

64. See http://www.wedo.org/. Accessed Jan 2013.

65. See http://www.wen.org.uk/. Accessed Jan. 2013.

66. See http://www.when.org/. Accessed Jan. 2013.

67. See the Division for the Advancement of Women (General Assembly 2006, 61 ${ }^{\text {st }}$ session). http://www.un.org/womenwatch/daw/documents/ga.htm. Accessed Jan. 2013.

Feminismo/s 22, diciembre 2013, pp. 17-46 
people and still continue to be discriminated against in their rights to have access to education. ${ }^{68}$

At a smaller scale, a good number of ecofeminist scholars have researched women's vulnerability to environmental pollution, largely to provoke national and international debates within academic circles. Examples include biologist Sandra Steingraber's research on industrial and environmental health, which centers on the connections between fetal and environmental degradation through the nine months of pregnancy and, beyond, through breastfeeding. Steingraber's work reveals the extent to which environmental hazards, from industrial poison found in amniotic fluid to the toxic contamination of breast milk, can threaten each crucial stage of the fetal development. ${ }^{69}$ Likewise, critiques of reproductive technology, genetic engineering and population control appeared largely discussed in the aforementioned "Reproductive Technology, or Reproductive Justice? An Ecofeminist Environmental Justice Perspective on the Rhetoric of Choice", where Greta Gaard develops an ecofeminist perspective on women's reproductive self-determination, concentrating on the modern affluence of fertility-enhancing technologies. In her own words, apart from concealing information about adverse health effects, the new reproductive technologies are "implicitly antifeminist because they blame the victim by attributing rising infertility rates to middle-class women who delay childbearing while striving to launch careers, and are forced to solicit egg donation and gestation services from women disadvantaged by economic status, nation and age." 70

It seems worth noting that, although for years much of the ecofeminist literature on social justice has persistently demonstrated how women's bodies are particularly vulnerable to environmental pollution ${ }^{71}$, historically, safe chemical loads and toxicity levels have tended to be officially calculated on the basis of men's body tolerance to exposure. Exceptionally, the new European legislation on chemicals (REACH - Registration, Evaluation, Authorization and Restriction of Chemical substances) has very recently begun to draw attention to the vulnerability to chemical exposure of pregnant women and children. ${ }^{72}$ But in spite of all these efforts, there are still few instances of

68. For the complete speech, see http://www.unwomen.org/2011/09/accelerating-gender-equality-worldwide-a-challenge-for-un-women/. Accessed Jan. 2013.

69. STEINGRABER, Sandra. Having Faith: An Ecologist's Journey to Motherhood.

70. GAARD, Greta. "Reproductive Technology?". Op. cit., pp. 103-129.

71. For insightful views on women's vulnerability to ecological degradation, see MELLOR, Mary. Feminism and Ecology, p. 2.

72. See the 299 issue of the European Commission on Science for Environmental Policy (27 September 2012), which highlights that "pregnancy and early life are critical stages for 
official recognition in the actual legislation of most countries, which means that there is still significant scope to develop an environmental justice case along the lines that women and children are more vulnerable to toxic exposure due both to their biology and to their social roles, which are more likely to consign them to poverty than men. In contrast, since the last decade, publications on environmental justice have consistently incorporated concerns about women into their analyses, and, more particularly, have included in their studies target groups of women additionally marginalized by their income, occupation, ethnicity or disability. ${ }^{73}$ These seem important inclusions since environmental justice issues are becoming widely heard all over the US and Northwest Europe. However, there is still much cause for concern. Social philosopher Iris Marion Young points out that, although in the last twenty-five years there have been significant changes in gendered norms of behavior and comportment with a great deal more freedom of choice now available to members of both sexes, "the basic structures of gender comportment are still implicitly male, and the sexual division of labor nevertheless continues to afford men more privilege and opportunity for access to resources, positions of power and authority." ${ }^{74}$ Similarly, in The Industrial Vagina (2008), Sheyla Jeffreys denounces an alarming increase of problems connected to the sex industry, namely "the precariousness of women's health, their vulnerability to organized crime and corruption, the increasing trafficking and the early sexualization of girls", and criticizes the opportunistic attitude of governments, sex workers activists and UN agencies which still take the comfortable position of not challenging the right of men to buy women's bodies for sex. ${ }^{75}$

Conclusively, despite real and potential differences, given the larger framework of postcolonial ecocriticism and considering the existing symmetries between ecofeminism and environmental justice, there seem to be sufficient reasons for both movements to become, once and for all, allies for:

(E)cofeminist values oppose all forms of hierarchy and domination, and environmental justice is a movement challenging the continued colonization of nature and marginalized humans, and powered by women at the

environmental chemical exposure", at http://ec.europa.eu/environment/integration/research/newsalert/pdf/299na6.pdf. Accessed Jan. 2013.

73. See Agyeman, Julian at al. eds. Just Sustainabilities. Development in an Unequal World.

74. Young, Marion. "Structural Injustice and the Politics of Difference", Social Justice and Public Policy, Gary Craig et al. eds., p. 88.

75. JefFreYs, Sheyla. The Industrial Vagina. The Political Economy of the Global Sex Trade, p. 16.

Feminismo/s 22, diciembre 2013, pp. 17-46 
grassroots, though its theory was initially articulated by men in leadership or in academe. ${ }^{76}$

To further the alliance, Gaard suggests concentrating on collaborative work in order to build on the "sexual justice branch" of the environmental justice movement, developing the lesbian ecocriticism deftly started by Catriona Mortimer-Sandilands and advancing on reproductive justice and environmental health both at grassroots and at academic levels. ${ }^{77}$

\section{Queer feminism and ecology}

In 1994, in a special issue of the Canadian journal Undercurrents, entitled Queer Nature, Gordon B. Ingram explicitly recognized the relationship between ecology and queer theory. Using the term "queer" to refer to "lesbian/ gay male/bisexual woman or man" ${ }^{78}$ Ingram denounces an over-emphasis on assessing the experience of straight white men and a persistent homophobia in most environmental groups, while at the same time he acknowledges the need to intensify the relationship between environmentalism, ecofeminism and queer theory to expand future activism. ${ }^{79}$ In the same volume, Catriona Sandilands questions the heteronormativity that has so far pervaded ecological discourse and further develops queer ecofeminism as a specific project for future research. ${ }^{80}$

Almost simultaneously, in "Toward a Queer Ecofeminism", Greta Gaard explores the historical, philosophical and religious roots of the connections between the oppression of queers and the domination of nature. Using a broad ecofeminist framework for her analysis, Gaard writes:

All those associated with nature and the erotic continue to experience the impact of centuries of Western culture's colonization, in our very bodies and in our daily lives. Rejecting that colonization requires embracing the erotic in all its diversity and building coalitions for creating a democratic, ecological culture based on our shared liberation. ${ }^{81}$

76. GAARD, Greta. "New Directions". Op. cit., p. 6.

77. Ibid., p. 6.

78. INGRAM, Gordon B. "Lost Landscapes and the Spatial Contextualization of Queerness", p. 8. Online at http://gordonbrentingram.ca/scholarship/wp-content/uploads/2008/12/ ingram-1994-lost-landscapes-and-the-spatial-contexualizaton-of-queerness.pdf. Accessed Jan. 2013.

79. Ibid., p. 5.

80. SANDILANDS, Catriona. "Lavender Green?". Op. cit., pp. 20-25.

81. GAARD, Greta. "Toward a Queer Ecofeminism", p. 132. Online at http://gretagaard. efoliomn.com/Uploads/QueerEcofeminism.pdf. Accessed Jan. 2013. 
In this groundbreaking essay, Gaard coins the term "erotophobia", or fear of the erotic, to explain the relationship between heterosexism and ecological degradation. Revising the long list of dualisms with which ecofeminists have characterized western culture, Gaard demonstrates that the eroticization of nature, in opposition to reason, has largely served to emphasize its subordination. Thus, taking the lead for a consideration of environmentalism as a sexual politics - a form of resistance to the disciplinary logic of heterosexism and patriarchy - Gaard understands that, from a queer ecofeminist perspective, the liberation of women necessarily requires the liberation of nature, of the erotic and of queers, thereby seeding the ground for further research in the fields of feminist materialism, ${ }^{82}$ and inspiring new philosophical analyses of heteronormativity and sexual oppression within a whole range of social practices and institutions. ${ }^{83}$

Drawing, among other sources, from Donna J. Haraway's A Cyborg Manifesto: Science, Technology and Socialist Feminism in the Late Twentieth Century ${ }^{84}$ where the distinction between the human and the other was first consistently blurred, in the introduction to her co-edited volume Queer Ecologies: Sex, Nature, Politics, Desire, Mortimer-Sandilands moves consistently forward with her previous work on feminism, culture and sexuality when she claims that the traditional opposition between nature and culture has been one of the causes of prejudiced social attitudes against women, animals and, more importantly, against women and animal queer behavior. As the Canadian feminist environmentalist explains, the first objective for modern queer theorists should be to challenge the split between nature and culture upon which the majority of charges against queers (mostly for being against nature) rest. ${ }^{85}$ In so doing, Mortimer-Sandilands explores the modern cultural tendency to boost a closer intimacy between humans and domesticated animals, a tendency which has facilitated the proliferation of studies on animal psychology. Some of these studies have proved the plurality of animal - and therefore human - sexuality, something which has become widely accepted in scientific circles. As a result, a whole array of scientific research conducted on this body of knowledge has served to illustrate the mistaken accusations of queer acts

82. For example, Grosz's work on Darwinism and feminism, in Alaimo and Hekman. Op. cit., pp. 23-51.

83. See, for example, chapters 4 and 5 of Adelle MCWHORTE's Bodies and Pleasures. Foucault and the Politics of Sexual Normalization.

84. In Simians, Cyborgs and Women: The Reinvention of Nature. Online at http://www9. georgetown.edu/faculty/irvinem/theory/Haraway-CyborgManifesto.html. Accessed June 2013.

85. Op. cit., pp. 31-32.

Feminismo/s 22, diciembre 2013, pp. 17-46 
and behavior as being against nature. ${ }^{86}$ However, contrary to what might be expected, modern queer theorists have not chosen to reclaim the naturalness of queer activity but, more ambitiously, have insisted on delegitimizing the binary constructions of animality and sexuality that have so far informed the scientific and cultural discussion of sex ${ }^{87}$ challenging the pairing of (hetero) sexuality and nature by developing deconstructive, reverse discourses that contest the dominant understandings of what society considers to be natural sexuality. ${ }^{88}$

Very possibly, the future of queer ecology lies in the design of new strategies to challenge the hegemony of heteronormativity, resisting the exploitation of nature as economic resource and public spectacle, and defying the obsession with queer consumerist lifestyles among popular artists, filmmakers and fashion designers. As Mortimer-Sandilands has put it, "the future of a green queer philosophy is to embrace deviation and strangeness as a necessary part of biophilia, considering sexual pleasure and cultural transgressions as foundational elements to a necessary environmental ethics and politics of resistance." $" 89$

\section{Conclusion}

Although significant achievements toward incorporating gender issues within some policy areas at local and global levels have been obtained, there is still a long way to go. In the above mentioned UN annual meeting speech, Lakshmi Puri challenges poor and rich, underdeveloped and fully developed, nondemocratic and democratic countries to respect women's rights and promote gender equality, and denounces situations of inequality in both nondemocratic and democratic countries, where women's voices are stifled under the burden of social, cultural and religious taboos and prejudices. The reality is that, to this day, only 28 countries in the world have achieved or surpassed the 30 percent critical mass for women's representation in parliament or in similar political institutions of power. ${ }^{90}$ Too many questions posited by feminist scholars still remain unanswered as much toxic waste and harmful chemicals continue

86. Ibid., p. 31.

87. Ibid., p. 32.

88. For an in-depth analysis of animal sexuality, in the same volume, see Noël STURGEON's "Penguin Family Values: The Nature of Planetary Environmental Reproductive Theory", pp. 102-133.

89. Ibid., p. 39.

90. Seehttp://www.unwomen.org/2011/09/accelerating-gender-equality-worldwide-a-challenge-for-un-women/. Accessed Jan. 2013. 
to affect women's and children's bodies, crimes are committed against men and women because of their sexual orientation, women's flesh is used to nurture phallocentric imaginations, reproductive injustice is practiced on human and nonhuman females, all this in a world where climate change is not only a believable possibility, but a palpable truth that affects the poor and the racially prejudiced more than anyone else.

In the present environmental state of affairs and considering the global economic crisis, ecofeminist activism asserts that women are better able to re-orient the nature of the mainstream, but they can only be effectively integrated into mainstreaming initiatives if more of them are included in decision-making institutions, creating the possibility that other women take part in the allocation and control of economic resources. For ecofeminist activism to advance, it must draw on the work of feminists, ecofeminists and environmentalists from around the world who can further cross-cultural dialogue and engage in local and global politics. ${ }^{91}$ Grassroots activism must expand its objectives and advocate for sexual justice for women, queers and nonhuman species, and ecofeminist theorists must contribute to influence local governments to build sustainable economies, affecting "the development of sustainable transportation, affordable housing, community-owned banks, systems and structures for agricultural and inter-species justice, pursuing socially responsible investment opportunities as well as equal marriage rights, and safe and affordable healthcare for all." ${ }^{92}$

Greta Gaard and Carol J. Adams, like the theorists previously mentioned, have successfully demonstrated that all forms of oppression function as interconnected and mutually reinforcing systems of culture which oppress women, animals and the environment in strikingly similar ways. The categories of "woman", "animal" and "nature" function in symbolically similar positions in patriarchal societies as dominated, objectified, consumed, and silenced referents. ${ }^{93}$ Similarly, Gordon B. Ingram considers that "an understanding of the

91. Apart from the ecofeminisms of the south, pioneered by Vandana Shiva and Bina Agarwal, in India, and Ivonne Guevara in South America, I would like to draw attention to the future possibilities of a rising ecofeminist branch of Spanish feminist philosophy which, initiated by $\mathrm{M}^{a}$ Xosé AGRA (Ecología y Feminismo), is currently led by feminist philosophers $\mathrm{M}^{a}$ Luisa CAVANA, Cristina SEgurA and Alicia Puleo (Mujeres y Ecología) and, most recently, by Alicia PULEO's Ecofeminismo para otro Mundo Posible. These feminist scholars are actively contributing to raise public concern for the ecofeminist cause amongst the general public, as well as amongst the members of the academia.

92. GAARD, Greta, "New Directions". Op. cit., p. 17.

93. See ADAMS, Carol J. The Sexual Politics of Meat. Op. cit., p. 51. For GAARD's contribution to the 2012 Hypatia symposium centered on "Speaking of Animal Bodies", see footnote no. 53.

Feminismo/s 22, diciembre 2013, pp. 17-46 
intensifying juncture of environmentalism, radical ecology, ecofeminism and queer theory is becoming crucial for the expansion of political activism in the coming decade." ${ }^{44}$ For, although, as Timothy Morton explains, "ecofeminism arose out of feminist separatism, wedded to a biological essentialism that is grounded on binary difference, ${ }^{\prime 95}$ the fact is that modern ecofeminist vectors point to a concept of nature as a number of interactive processes, never products, their main objective being "the sheer, open appreciation of otherness, beyond tolerance, free to experience intimacy with other beings." D. Murphy has pleaded for the validity of ecofeminist analysis and "the ethical necessity to extend ecofeminist rhetorical critique in the long emergency of the climate change crisis." ${ }^{.97}$ More specifically, ecofeminism's interest in exploring the inclusiveness, transversality and porosity - to borrow the words of some of the aforementioned theorists - of the human relationships with nonhuman others, and its emphasis on processes, fluid boundaries and dynamic interactions preclude the future relevance of a wide range of "intersectional analyses" - echoing Murphy again - within ecofeminist rethorics, a critical methodology which is becoming increasingly important in the widening range of ecofeminist concern. In spite of the real obstacles that remain in the horizon, it seems plausible that modern ecofeminist theoreticians will find the right strategies to cause real structural reforms in the existing social systems. Even more arduous seems the ecofeminist activists' challenge to create the necessary coalitions that can provoke change in the fastest and most effective ways.

\section{Bibliographic References}

ADAmS, Carol J. The Sexual Politics of Meat. 1990. New York: Continuum, 2010.

— "Why Feminist-Vegan Now?", Feminism and Psychology 20(3), 2010. 301-317.

ADAmson, Joni and Scott Slovic, eds. "The Shoulders We Stand On: An Introduction to Ethnicity and Ecocriticism", MELUS: Multi-Ethnic Literature of the USA, vol. 34, no. 2 (Summer 2009). Pp. 5-24.

AGRA, Ma Xosé. Ecología y Feminismo. Granada: Editorial Comares, 1998.

AgYeman, Julian at al. eds. Just Sustainabilities. Development in an Unequal World. London: Earthscan Publications, 2003: pp. 229-251.

94. Op. cit., p. 5.

95. MORTON, Timothy, "Queer Ecology", p. 274. Online at http://www.academia. edu/1050754/Queer_Ecology. Accessed Jan. 2013.

96. Ibid., p. 280.

97. See MurPhy, Patrick D. Afterword to Douglas A. VAKOCH ed. Ecofeminism and Rethoric. Op. cit., p. 145. 
AHMED, Sarah. Queer Phenomenology. Orientations, Objects, Others. Durham, NC: Duke University Press, 2006.

Alaimo, Stacy and Susan Hekman eds. Material Feminisms. Bloomington: Indiana University Press, 2008.

Armbruster, Karla. "What Do We Want from Talking Animals", in Speaking for Animals. Animal Autobiographical Writing. Ed. Margo DeMello. New York: Routledge, 2013: pp. 17-34.

BARAD, Karen. "Getting Real: Technoscientific Practices and the Materialization of Reality", Differences: A Journal of Feminist Cultural Studies. 10.2, (1998). Pp. 87-128.

- Barad, Karen. Interview in New Materialism: Interviews and Cartographies. Dolphin, Rick and Iris Van Der Tuin eds. Ann Arbor: University of Michigan Library/Open Humanities Press, 2012. pp. 48-70. http://uu.academia.edu/ IrisvanderTuin. Accessed Jan. 2013.

BARRETT, Estelle and Barbara Bolt eds. Carnal Knowledge. Towards a New Materialism Through the Arts. London: IB Tauris and Co., 2013.

BIRKE, Lynda and Luciana Parisi. "Animals, Becoming", Animal Others: On Ethics, Ontology and Animal Life, Peter Steeves ed. Albany: State University of New York Press, 1999. Pp. 55-74.

Bordo, Susan. "Casey's Hair". Material Feminisms Alaimo, Stacy and Susan Hekman eds. Bloomington: Indiana University Press, 2008. Pp. 400-424.

Bostrom, Nick. "Why I Want to Be a Posthuman When I Grow Up", Medical Enhancement and Posthumanity, Bert Gordijn and Ruth Chadwick eds. (Spring 2008). Pp. 107-137. http://www.nickbostrom.com/posthuman.pdf. Accessed Jan. 2013.

BuCKIngham, Susan. "Ecofeminism in the $21^{\text {st }}$ Century", The Geographical Journal, 170.2: 146-154. http://www.studymode.com/essays/Ecofeminism-In-The-21St-Century-414055.html. Accessed Jan. 2013.

CARR, Glynnis. Foreword to Ecofeminism and Rethoric: Critical Perspectives on Sex, Technology and Discourse. Douglas A. Varoch ed. New York: Berghahn Books, 2011. ix-xvii.

Cavana, Ma Luisa, Cristina Segura and Alicia Puleo. Mujeres y Ecología. Madrid: Al-Mudayna, 2004.

Coole, Diane and Samantha Frost eds. New Materialism. Ontology, Agency and Politics. Durham, NC: Duke University Press, 2010.

DALY, Mary. Gyn/Ecology: the Metaethics of Radical Feminism. London: Women's Press, 1978.

DERRIDA, Jacques. Of Grammatology (trans. Gayatri Chakravorty). Baltimore: The Johns Hopkins University Press, 1974.

Feminismo/s 22, diciembre 2013, pp. 17-46 
DolPHIN, Rick and Iris Van Der Tuin. New Materialism: Interviews and Cartographies. Ann Arbor: University of Michigan Library/Open Humanities Press, 2012. http://uu.academia.edu/IrisvanderTuin. Accessed Jan. 2013.

GAARD, Greta, S. C. Estok and S. Oppermann eds. International Perspectives in Feminism Ecocriticism. New York and London: Routledge, 2013.

- "New Directions for Ecofeminism: Toward a More Feminist Ecocriticism", ISLE, vol. 17, no. 4, (Autumn 2010). Pp. 643-665. Published online (Oct. 1, 2010. 1-23). http://gretagaard.efoliomn.com/Uploads/isle.isq108.full.pdf. Accessed Jan. 2013.

- "Speaking of Animal Bodies", Hypatia, 27.3 (August 2012). http://onlinelibrary.wiley.com/doi/10.1111/hypa.2012.27.issue-3/issuetoc. Accessed Jan. 2013. http://thephilosopherseye.com/2012/07/09/hypatia-symposium-greta-gaard/. Accessed Jan. 2013.

- "Reproductive Technology or Reproductive Justice? An Ecofeminist Environmental Justice Perspective on the Rhetoric of Choice", Ethics and the Environment, vol. 15 no. 2 (Fall 2012). Pp. 103-129.

— "Ecofeminism Revisited: Rejecting Essentialism and Re-Placing Species in a Material Feminist Environmentalism", Feminist Formations, vol. 23 no. 2 (Summer, 2011). Pp. 26-53. http://www.readbag.com/gretagaard-efoliom n-uploads-ecofeminismrevisited2011. Accessed Jan 2013.

— "Strategies for a Cross-Cultural Ecofeminist Literary Criticism", Ecozon@, vol. 1 no. 1 (2010). Pp. 47-52.

Grosz, Elizabeth. "Darwin and Feminism. Preliminary Investigations for a Possible Alliance", Material Feminisms, Stacy Alaimo and Susan Hekman eds. Bloomington: Indiana University Press, 2008. Pp. 23-51.

GUATTARI, Félix. Las Tres Ecologías (trad. José Vásquez y Umbelina Larraceleta). Valencia: PRE-TEXTOS, 1996. http://www.arteuna.com/talleres/lab/ediciones/FelixGuattariLastresecologas.pdf. Accessed Jan. 2013.

HARAWAY, Donna. "The Promises of Monsters: A Regenerative Politics of Inappropriate/d Others", Cultural Studies, Lawrence Gossberg et al. eds. New York: Routledge, 1992. Pp. 295-337. http://www.zbi.ee/ kalevi/monsters.html. Accessed Nov. 2012.

—When Species Meet. Minneapolis: University of Minnesota Press, 2008.

-The Companion Species Manifesto: Dogs, People, and Significant Otherness. Chicago: University of Chicago Press, 2003.

-Simians, Cyborgs and Women: The Reinvention of Nature. New York: Routledge, 1991. 149-181. http://www9.georgetown.edu/faculty/irvinem/theory/Haraway-CyborgManifesto.html. Accessed June 2013.

Holmberg, Tora. "Mortal Love: Care and Practices in Animal Experimentation", Feminist Theory, vol. 12 (2) (August 2011). Pp. 147-163. http://fty.sagepub. com/content/12/2.toc. Accessed Nov. 2012. 
INGRAM, Gordon B. "Lost Landscapes and the Spatial Contextualization of Queerness", Undercurrents. Critical Environmental Studies (May 1994). 4-9. http://gordonbrentingram.ca/scholarship/wp-content/uploads/2008/12/ingram-1994-lost-landscapes-and-the-spatial-contexualizaton-of-queerness. pdf. Accessed Jan. 2013.

IOvINO, Serenella. "Theorizing Material Ecocriticism: A Diptych", ISLE vol. 19.3 (Summer 2012). 448-475. http://www.academia.edu/Documents/in/Material_Ecocriticism. Accessed June 2013.

Jeffreys, Sheyla. The Industrial Vagina. The Political Economy of the Global Sex Trade. New York: Routledge, 2009.

Johnson, Jim. "Mixing Humans and Nonhumans Together: The Sociology of a Door-Closer", Social Problems, vol. 35, no. 3 (June, 1988). 298-310. http:// www.jstor.org/discover/10.2307/800624? uid=3737952\&uid=2\&uid=4\&s $\mathrm{id}=21103051780571$. Accessed Dec. 2013.

JONES, pattrice. Aftershock: Confronting Trauma in a violent World. New York: Lantern Books, 2007.

- Sistah Vegan. New York: Lantern Books, 2010.

KAO, Grace. "Consistency in Ecofeminist Ethics", The International Journal of Humanities, vol. 3 no. 11 (2005). 11-22. http://www.rc.vt.edu/religious/pdfs/ Kao_Ecofeminist\%20Ethics.pdf. Accessed Jan. 2013.

KHEEL, Marti. Nature Ethics. An Ecofeminist Perspective. Lanham, Maryland: Rowman and Littlefield, Inc, 2008.

McWhorter, Adelle. Bodies and Pleasures. Foucault and the Politics of Sexual Normalization. Bloomington: Indiana University Press, 1999. Pp. 100-175.

Mellor, Mary. Feminism and Ecology. Cambridge: Polity Press, 1997.

Merchant, Carolyn. The Death of Nature: Women, Ecology and the Scientific Revolution. 1980. New York: Harper, 1989.

- Earthcare, Women and the Environment. New York: Routledge, 1996.

Mortimer-SAndilandS, Catriona and Bruce Erickson eds. Queer Ecologies: Sex, Nature, Politics, Desire. Bloomington: Indiana University Press, 2010.

Mortimer-SANDILANDS, Catriona. "Lavender Green? Some Thoughts on Queer(y) ing Environmental Politics". Undercurrents 6.1 (May 1994). Pp. 20-24.

MorTOn, Timothy, "Queer Ecology”, PMLA, 125.2 (March 2010). Pp. 273-282. http://www.academia.edu/1050754/Queer_Ecology. Accessed Jan. 2013.

MurPhy, Patrick D. Afterword to Ecofeminism and Rhetoric. Critical Perspectives on Sex, Technology and Discourse. Douglas A. Varoch ed. New York: Berghahn Books, 2011. Pp. 145-156.

Plumwood, Val. Environmental Culture: The Ecological Crisis of Reason. New York: Routledge, 2002.

- Feminism and the Mastery of Nature London and New York: Routledge, 1993.

Puleo, Alicia. Ecofeminismo para otro Mundo Posible. Madrid: Cátedra, 2011.

Feminismo/s 22, diciembre 2013, pp. 17-46 
REgAn, Tom. The Case for Animal Rights. Berkeley and Los Angeles, CA: University of California Press, 1983.

REY, Esther. “¿Por qué ellas? ¿por qué ahora? Orígenes y Evolución de la Síntesis Ecofeminista", Ecocríticas. Literatura y Medioambiente. Eds. Carmen Flys et al. Madrid: Iberoamericana-Vervuert, 2010. Pp. 135-166.

SAlleH, Ariel K. "Deeper than Deep Ecology: The Eco-Feminist Connection", Environmental Ethics 6, no. 4 (Winter 1984). Pp. 339-45.

SEAGER, Joni. "Pepperoni or Broccoli? On the Cutting Edge of Feminist Environmentalism", Gender, Place and Culture: A Journal of Feminist Geography, vol. 3, issue 2, 2003. Pp. 167-174.

Singer, Peter. (1975) Animal Liberation. New York: Harper, 2009.

SPRETNAK, Charlene. "Our Roots and Our Flowering", Reweaving the World. The Emergence of Ecofeminism. Irene Diamond and Gloria Orenstein eds. San Francisco: Sierra Club Books, 1990. Pp. 3-14.

SQuiER, Susan and Melissa M. Littlefield. "Feminist Theory and/of Science", Feminist Theory, 5.2 (2004). Pp. 123-26.

SteIngraber, Sandra. Having Faith: An Ecologist's Journey to Motherhood, New York: The Berkeley Publishing Group, 2003.

StURGEON, Noël, "Penguin Family Values: The Nature of Planetary Environmental Reproductive Theory", Queer Ecologies: Sex, Nature, Politics, Desire. Catriona Mortimer-Sandilands and Bruce Erickson eds. Bloomington: Indiana University Press, 2010. Pp. 102-133.

- Ecofeminist Natures. Race, Gender, Feminist Theory and Political Action. New York: Routledge, 1997.

TUANA, Nancy. "Viscous Porosity: Witnessing Katrina", Material Feminisms. Stacy Alaimo and Susan Hekman eds. Bloomington: Indiana University Press, 2008. Pp. 188-213.

WArren, Karen J., ed. Ecological Feminist Philosophies. Bloomington: Indiana University Press, 1996.

YOUNG, Marion. "Structural Injustice and the Politics of Difference", Social Justice and Public Policy, Gary Craig et al. eds. Bristol: The Policy Press, 2008. 